\section{Development and Testing of Preliminary Foliar DRIS Norms for Onions}

\author{
Jordan O'N Caldwell ${ }^{1}$, Malcolm E. Sumner, and Charles S. Vavrina ${ }^{2}$ \\ Department of Crop and Soil Sciences, University of Georgia, Athens, \\ GA 30602
}

Additional index words. Diagnosis and Recommendation Integrated System, tissue analysis, nutrient balance, Allium cepa

\begin{abstract}
The Diagnosis and Recommendation Integrated System (DRIS) was developed to incorporate the importance of nutrient balance into plant analysis. Yield and plant analysis data from five fertilizer trials conducted in the field during 2 years, using ' $G$ ranex 33' onions (Allium cepa $\mathrm{L}$.), were entered into a data bank. The trials consisting of a $\mathrm{N}^{4} \times$ $\mathbf{P}^{4} \times K^{4} \times S^{4}$, a $N^{4} \times P^{4} \times K^{4} \times$ plant density ${ }^{4}$, two $N^{4} \times P^{4} \times K^{4}$, and a $4 N \times 6 S$ factorial were conducted on sandy Ultisols in Georgia. Significant yield responses resulted from the addition of $\mathrm{P}$ and $\mathrm{N}$. Leaf samples were analyzed for $\mathrm{N}, \mathrm{P}, \mathrm{K}, \mathrm{S}, \mathrm{Ca}, \mathrm{Mg}, \mathrm{Mn}, \mathrm{Zn}, \mathrm{Cu}$, and B. Nutrient data were expressed in ratio form, and the population with yields $>45 \mathrm{Mg} \cdot \mathrm{ha}^{-1}$ were used to calculate the DRIS norms. The proposed norms for $\mathrm{N}, \mathrm{P}, \mathrm{K}, \mathrm{Mg}$, and $\mathrm{Cu}$ were tested using published data from independently conducted field and greenhouse studies. By accurately diagnosing the most limiting nutrients, these norms successfully predicted yield responses to treatment. Preliminary norms for $\mathrm{S}, \mathrm{Ca}, \mathrm{Mn}, \mathrm{Zn}$, and $\mathrm{B}$ were determined but not tested.
\end{abstract}

Onions are grown extensively in the United States, with nearly 50,000 ha in production. However, there is some disagreement among researchers concerning the nutritional status necessary for good yields. Some researchers have proposed critical values or sufficiency ranges for the major nutrients (Table 1). Minimum nutrient concentration ranges proposed are $1.9 \%$ to $4.0 \%$ for $\mathrm{N}, 0.18 \%$ to $0.43 \%$ for $\mathrm{P}$, and $1.7 \%$ to $4.5 \%$ for $\mathrm{K}$. With such a diversity in the proposed values, more work is required for tissue analysis to be effective in revealing nutritional disorders in onions.

In the past decade, inadequacies in the critical value and sufficiency range approaches to plant analysis have been pointed out (Walworth and Sumner, 1988). Most critical value and sufficiency range approaches involve curve-fitting techniques using data from single-factor fertilizer experiments. The point at which no further significant yield increases occur is selected as the critical value; otherwise, a range plus or minus some percentage of a critical value is designated as the sufficiency range. While the single factor in question is varied, the researcher attempts to maintain all the other growth factors at their opti-

Received for publication 2 Aug. 1993. Accepted for publication 16 Apr. 1994. The cost of publishing this paper was defrayed in part by the payment of page charges. Under postal regulations, this paper therefore must be hereby marked advertisement solely to indicate this fact.

${ }^{1}$ Current address: Dept. of Soil and Crop Sciences, Texas A\&M Univ., College Station, TX 778432474.

${ }^{2}$ Department of Horticulture Extension, Univ. of Georgia, Athens, GA 30602. Current address: Southwest Florida Research and Education Center, Immokalee, FL 33934. mum. This approach assumes that the effects of the treatments on the other factors will be neutral. Also, the optimum level for the other factors must be known beforehand. In estimating the nutritional status of a plant, the critical value and sufficiency range approaches consider each component separately and ignore nutritional balance.

The importance of elemental balance, as opposed to the mere concentration of $\mathrm{K}, \mathrm{Ca}$, and $\mathrm{Mg}$, was first recognized in grapes by Lagatu and Maume (1924). In experiments on tung trees, the concept of elemental balance was expanded to include 12 of the essential plant nutrients (Shear et al., 1946). These authors stated succinctly: "All other factors being constant, plant growth is a function of the two variables of nutrition, intensity and balance." It was not until Physiological Diagnosis was developed by Beaufils (1957), later renamed the Diagnosis and Recommendation Integrated System (DRIS) (Beaufils, 1973), that the impact of elemental balance could be quantified. The DRIS approach, which uses nutrient ratios, has been reviewed extensively (Sumner, 1990; Walworth and Sumner, 1987). DRIS values have also been shown to be diagnostically superior to the critical value and sufficiency range approaches (Angeles et al., 1990; Elwali and Gascho, 1984).

Each nutrient ratio has two forms, e.g., N/ $\mathrm{P}$ and $\mathrm{P} / \mathrm{N}$. Traditionally, the ratio that results in the most significant variance ratio between the low- and high-yielding populations is selected to be used in calculations (Beaufils, 1957). This procedure is intended to determine the norms with the greatest predictive precision. In an effort to increase the predictive precision of DRIS, other norm selection methods have been proposed. Davee et al. (1986) used four different procedures to pick the norms to be included. There were no significant changes in the predictive ability of the norms selected by the procedures. Three selection methods were evaluated on Fraser firs [Abies fraseri (Pursh) Poeret], but again no significant predictive precision was produced (Rathfon and Burger, 1991).

We found insufficient data in the literature to establish an adequate database from which to calculate foliar norms for onions. Therefore, we conducted large, factorial fertilizer trials designed to provoke yield variability in the field. A similar approach to generating a DRIS data bank was previously carried out for sunflowers [Helianthus annuus (L.)] (Grove and Sumner, 1982). The purpose of our study was to create such a data bank from which preliminary foliar DRIS norms for onions could be calculated. The diagnostic value of the proposed norms was tested using data from independently conducted experiments reported in the literature.

\section{Materials and Methods}

Fertilizer application. Data used to develop the foliar DRIS norms were taken from five factorial fertilizer trials conducted in the field from 1988 to 1990 . In 1988-89, field experiments were undertaken in Chatham County, Ga., on an Albany fine sand (thermic, Grossarenic Paleudult). The experiments consisted of an $\mathrm{N}^{4} \times \mathrm{P}^{4} \times \mathrm{K}^{4} \times \mathrm{S}^{4}$ factorial with complete confounding in units of 64 (Expt. 1); and two $\mathrm{N}^{4} \times \mathrm{P}^{4} \times \mathrm{K}^{4}$ factorials with complete confounding in units of 16 (Expts. 2 and 3 ). Each plot in Expts. 1-3 was later split. The main treatments included $84,168,336$, and $672 \mathrm{~kg} \mathrm{~N} / \mathrm{ha}$ as calcium nitrate; 39, 79, 157, and $315 \mathrm{~kg}$ P/ha as triple superphosphate; 41, 83,166 , and $332 \mathrm{~kg} \mathrm{~K} / \mathrm{ha}$ as potassium chloride; and, in Expt. 1 only, 0, 34, 68, and $136 \mathrm{~kg}$ $\mathrm{S} / \mathrm{ha}$ as gypsum. Each field received an initial application of micronutrients to supply $\mathrm{Mn}$, $\mathrm{Zn}, \mathrm{Fe}, \mathrm{Cu}, \mathrm{B}$, and $\mathrm{Mg}$ at 5.6, 3.4, 4.5, 3.4, 1.7, and $56 \mathrm{~kg} \cdot \mathrm{ha}^{-1}$, respectively. Phosphorus and S, along with $20 \%$ of the $\mathrm{N}$ and $33 \%$ of the K, were broadcast before planting and rototilled to a depth of $20 \mathrm{~cm}$. Onion seedlings ( 'Granex 33') were transplanted on 13-15 Dec. 1988, $10 \mathrm{~cm}$ apart in rows $36 \mathrm{~cm}$ apart, resulting in a plant population of 22 plants $/ \mathrm{m}^{2}$. The remainder of the $\mathrm{N}$ and $\mathrm{K}$ was broadcast in three equal amounts on 4 Jan., 18 Jan., and 8 Feb. Also on 8 Feb., split applications of gypsum were applied to a randomly selected half of each plot in Expt. 1. On 1 Feb., split applications of triple superphosphate were applied to a random half of each plot of Expts. 2 and 3. Each split treatment of gypsum and phosphate was equivalent to the initial $\mathrm{S}$ or $\mathrm{P}$ treatment rate for the whole plot. Tissue samples were collected on 8 Mar. 1989. All plots consisted of raised beds $1.5 \times 4.5 \mathrm{~m}$. Onions were harvested on 20 May.

Experiment 1 was repeated in 1989-90, except that a planting density treatment was substituted for the nonsignificant $\mathrm{S}$ treatment and is referred to as Expt. 4. Due to a lack of significant yield response to $\mathrm{K}$ in the previous year, the K levels were adjusted to $0,83,166$, 
Soll Management, Fertilization, \& Irrigation

Table 1. Proposed critical values and sufficiency ranges for onion tissue

\begin{tabular}{|c|c|c|c|c|c|c|c|c|}
\hline \multicolumn{5}{|c|}{ Nutrient } & \multirow{3}{*}{$\begin{array}{l}\text { Plant } \\
\text { part }^{z}\end{array}$} & \multirow{3}{*}{$\begin{array}{c}\text { Growth } \\
\text { stage }^{y}\end{array}$} & \multirow{3}{*}{$\begin{array}{l}\text { Type } \\
\text { expt. }\end{array}$} & \multirow[b]{3}{*}{ Source } \\
\hline $\mathrm{N}$ & $\mathrm{P}$ & K & $\mathrm{Ca}$ & $\mathrm{Mg}$ & & & & \\
\hline \multicolumn{5}{|c|}{ Nutrient in dry matter (\%) } & & & & \\
\hline $2.5-3.5$ & $0.25-0.40$ & $2.5-5.0$ & $1.5-3.5$ & $0.30-0.50$ & YMB & MG & $\mathrm{S}$ & Piggott (1986) \\
\hline $3.0-3.8$ & $0.27-0.40$ & $2.0-3.4$ & $0.9-1.7$ & $0.18-0.38$ & YMB & B & G & Pankov (1984) \\
\hline 4.0 & $0.43-0.45$ & $4.5-4.6$ & $\mathrm{ND}^{\mathrm{w}}$ & ND & YMB & $\mathrm{B}_{2.5 \mathrm{~cm}}$ & $\mathrm{~F}$ & Painter (1977) \\
\hline $2.7-3.0$ & $0.30-0.40$ & $2.5-2.7$ & ND & ND & $\mathrm{T}$ & $\mathrm{B}$ & $\mathrm{F}$ & Bishop et al. (1972) \\
\hline $1.9-2.3$ & $0.18-0.30$ & $1.7-2.1$ & ND & ND & W & $3 m$ & G & van Lierop et al. (1980) \\
\hline
\end{tabular}

${ }^{2} \mathrm{YMB}=$ youngest mature blade; $\mathrm{W}=$ whole plant; $\mathrm{T}=$ tops.

${ }^{\mathrm{y}} \mathrm{B}=$ bulbing; $3 \mathrm{~m}=3$ months; $\mathrm{MG}=$ mid-growth.

${ }^{\mathrm{x}} \mathrm{S}=$ survey; $\mathrm{G}=$ greenhouse; $\mathrm{F}=$ field.

${ }^{\mathrm{w}} \mathrm{ND}=$ not determined.

and $332 \mathrm{~kg} \cdot \mathrm{ha}^{-1}$. Dolomitic lime was applied to the entire field at a rate of $1000 \mathrm{~kg} \cdot \mathrm{ha}^{-1}$ and incorporated. The planting pattern used equidistant spacing with four population densities: $28,36,45$, and 56 plants $/ \mathrm{m}^{2}$. All of the P, $10 \%$ of the $\mathrm{N}$, and $50 \%$ of the $\mathrm{K}$ was applied and incorporated before planting. Onion seedlings were transplanted on 21 Nov. 1989. The remaining $\mathrm{N}$ was broadcast in three applications of $20 \%$ (3 Jan.), 30\% (21 Jan.), and 40\% (17 Feb.). The remaining $\mathrm{K}$ was applied on $21 \mathrm{Jan}$. Onions were harvested on 5 May 1990.

Also during 1989-90, a study was conducted in Tatnall County, Ga., on a field previously cropped to soybeans [Glycine max (L.) Merrill] on a Tifton loamy sand (thermic, Plinthic Kandiudult). The design was a $\mathrm{N}^{4} \times \mathrm{S}^{6}$ randomized factorial with two replications (Expt. 5). The levels of $\mathrm{N}$ were 56, 112, 225, and $450 \mathrm{~kg} \cdot \mathrm{ha}^{-1}$ as calcium nitrate, and $\mathrm{S}$ at 0 , $11,22,45,90$, and $180 \mathrm{~kg} \cdot \mathrm{ha}^{-1}$ as gypsum. All of the $\mathrm{S}$ and $10 \%$ of $\mathrm{N}$ was broadcast and incorporated before planting, as previously described. The remaining $\mathrm{N}$ was broadcast in three applications of $20 \%, 30 \%$, and $40 \%$, as described above (Expt. 4). Tissue samples were collected for both experiments on 19 Mar. 1990. Onions were harvested on 28 Apr. 1990.

Tissue sampling. Tissue samples consisting of the last matured leaf were collected at bulbing; composite samples of 10 leaves were taken per plot. Tissue samples were dried for $24 \mathrm{~h}$ at $80 \mathrm{C}$ and ground in a Wiley mill to pass a $0.833-\mathrm{mm}$ opening (20 mesh) screen. Samples were dry-ashed at 500C, and P, K, $\mathrm{Ca}, \mathrm{Mg}, \mathrm{Cu}, \mathrm{B}, \mathrm{Mn}$, and $\mathrm{Zn}$ were analyzed in a $\mathrm{Li}_{2} \mathrm{CO}_{3} / \mathrm{HNO}_{3}$ buffer by arc-spark spectrophotometry. Total $\mathrm{N}$ content was determined by colorimetry on a flow-injection system after digestion by micro-Kjeldahl, and $\mathrm{S}$ by a sulfur determinator (model SC 132; Leco Corp., August, Ga.) (Isaac and Johnson, 1984). Onions were harvested, dried, and sorted by diameter $(<5,5-7.5$, and $>7.5 \mathrm{~cm})$. Recorded yields were adjusted to reflect the market value difference between grades as follows: yield of bulbs $<5 \mathrm{~cm}$ in diameter was multiplied by 0.5 and that for 5 - to $7.5-\mathrm{cm}$-diameter bulbs by 0.8 . Significant treatment effects

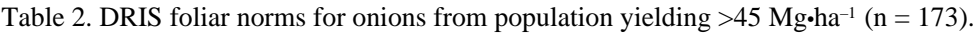

\begin{tabular}{|c|c|c|c|c|c|}
\hline Expression $^{z}$ & Mean & $\mathrm{CV}(\%)$ & Expression & Mean & $\mathrm{CV}(\%)$ \\
\hline$\overline{\mathrm{N}}$ & 3.68 & 16 & $\mathrm{Mg} / \mathrm{K}$ & 0.09 & 69 \\
\hline $\mathrm{P}$ & 0.37 & 29 & $\mathrm{~S} / \mathrm{K}$ & 0.12 & 47 \\
\hline $\mathrm{K}$ & 3.10 & 36 & $\mathrm{Mn} / \mathrm{K}$ & 35.75 & 60 \\
\hline $\mathrm{S}$ & 0.36 & 57 & $\mathrm{Zn} / \mathrm{K}$ & 10.60 & 50 \\
\hline $\mathrm{Ca}$ & 1.37 & 34 & $\mathrm{Cu} / \mathrm{K}$ & 6.62 & 114 \\
\hline $\mathrm{Mg}$ & 0.24 & 33 & $\mathrm{~B} / \mathrm{K}$ & 3.78 & 53 \\
\hline $\mathrm{Mn}$ & 100.14 & 49 & $\mathrm{Mg} / \mathrm{Ca}$ & 0.19 & 42 \\
\hline $\mathrm{Zn}$ & 30.21 & 48 & $\mathrm{~S} / \mathrm{Ca}$ & 0.31 & 85 \\
\hline $\mathrm{Cu}$ & 16.74 & 70 & $\mathrm{Mn} / \mathrm{Ca}$ & 76.86 & 48 \\
\hline B & 10.62 & 43 & $\mathrm{Zn} / \mathrm{Ca}$ & 25.00 & 70 \\
\hline $\mathrm{P} / \mathrm{N}$ & 0.10 & 36 & $\mathrm{Cu} / \mathrm{Ca}$ & 12.53 & 62 \\
\hline $\mathrm{K} / \mathrm{N}$ & 0.85 & 39 & $\mathrm{~B} / \mathrm{Ca}$ & 8.93 & 67 \\
\hline $\mathrm{Ca} / \mathrm{N}$ & 0.39 & 37 & $\mathrm{~S} / \mathrm{Mg}$ & 1.74 & 78 \\
\hline $\mathrm{Mg} / \mathrm{N}$ & 0.07 & 41 & $\mathrm{Mn} / \mathrm{Mg}$ & 492.91 & 79 \\
\hline $\mathrm{S} / \mathrm{N}$ & 0.10 & 54 & $\mathrm{Zn} / \mathrm{Mg}$ & 151.28 & 72 \\
\hline $\mathrm{Mn} / \mathrm{N}$ & 28.66 & 53 & $\mathrm{Cu} / \mathrm{Mg}$ & 77.18 & 72 \\
\hline $\mathrm{Zn} / \mathrm{N}$ & 7.82 & 45 & $\mathrm{~B} / \mathrm{Mg}$ & 49.56 & 58 \\
\hline $\mathrm{Cu} / \mathrm{N}$ & 4.83 & 73 & $\mathrm{Mn} / \mathrm{S}$ & 331.70 & 55 \\
\hline $\mathrm{B} / \mathrm{N}$ & 2.83 & 40 & $\mathrm{Zn} / \mathrm{S}$ & 95.95 & 52 \\
\hline $\mathrm{K} / \mathrm{P}$ & 9.34 & 50 & $\mathrm{Cu} / \mathrm{S}$ & 59.33 & 89 \\
\hline $\mathrm{Ca} / \mathrm{P}$ & 4.23 & 53 & $\mathrm{~B} / \mathrm{S}$ & 32.00 & 42 \\
\hline $\mathrm{Mg} / \mathrm{P}$ & 0.69 & 40 & $\mathrm{Zn} / \mathrm{Mn}$ & 0.34 & 52 \\
\hline $\mathrm{S} / \mathrm{P}$ & 1.03 & 50 & $\mathrm{Cu} / \mathrm{Mn}$ & 0.18 & 63 \\
\hline $\mathrm{Mn} / \mathrm{P}$ & 312.28 & 70 & $\mathrm{~B} / \mathrm{Mn}$ & 0.12 & 51 \\
\hline $\mathrm{Zn} / \mathrm{P}$ & 88.00 & 52 & $\mathrm{Cu} / \mathrm{Zn}$ & 0.66 & 83 \\
\hline $\mathrm{Cu} / \mathrm{P}$ & 51.05 & 86 & $\mathrm{~B} / \mathrm{Zn}$ & 0.38 & 41 \\
\hline $\mathrm{B} / \mathrm{P}$ & 30.12 & 40 & $\mathrm{~B} / \mathrm{Cu}$ & 0.84 & 67 \\
\hline $\mathrm{Ca} / \mathrm{K}$ & 0.54 & 78 & & & \\
\hline
\end{tabular}

${ }^{2}$ Concentrations of $\mathrm{N}, \mathrm{P}, \mathrm{K}, \mathrm{S}, \mathrm{Ca}$, and $\mathrm{Mg}$ are expressed in percent dry weight, and those of $\mathrm{Mn}, \mathrm{Zn}, \mathrm{Cu}$, and $\mathrm{B}$ in $\mathrm{mg} \cdot \mathrm{kg}^{-1}$. were determined by analysis of variance (SAS Institute, 1983). To determine significant differences, error terms in Expts. 1 and 4 contained three-way interactions, and Expts. 2 and 3 contained two-way interactions.

Calculation of norms. Using standard procedures (Beaufils, 1973), DRIS foliar norms and their coefficients of variation were calculated using the yield and tissue data from the experiments. The adjusted yields were separated into low- and high-yielding populations

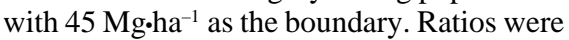
selected to meet the requirements of a computer program developed in our laboratory for the calculation of nutrient ratios and are therefore not random (Letzsch and Sumner, 1983). This same procedure has been used successfully in previous work (Angeles et al., 1990).

The progressive diagnosis procedure was used to test the validity of the norms (Sumner, 1977). This process involves testing the proposed norms using published data from factorial fertility trials in which significant yield responses to treatments were recorded. Using the determined foliar data for each treatment, DRIS indices were calculated in the traditional way (Beaufils, 1973). An example of these calculations is presented below using the hypothetical nutrients A through $\mathrm{N}$ :

where, for example

where $\mathrm{z}$ is the number of functions included in the equation, the lowercase ratios represent the particular norm while the uppercase ratios represent the measured nutrient values and $\mathrm{CV}$ is the coefficient of variation (percentage). A function is added to the nutrient index calculation when that nutrient appears in the numerator of the function, otherwise it is subtracted. The equations for calculating the N, P, and $\mathrm{K}$ indices when provided with only N, P, K tissue data are presented below, using as an example 
Table 3. Effects of N, P, and K fertilization on leaf composition, yield, and DRIS indices for onions from field data (Minotti and Stone, 1988).

\begin{tabular}{|c|c|c|c|c|c|c|c|}
\hline \multirow[b]{2}{*}{ Treatment $^{z}$} & \multicolumn{3}{|c|}{ Leaf composition (\% dry wt) } & \multicolumn{3}{|c|}{ DRIS indices } & \multirow{2}{*}{$\begin{array}{c}\text { Yield } \\
\left(\mathrm{Mg}^{2} \mathrm{ha}^{-1}\right)\end{array}$} \\
\hline & $\mathrm{N}$ & $P$ & $\mathrm{~K}$ & $\mathrm{~N}$ & $\mathrm{P}$ & $\mathrm{K}$ & \\
\hline$\overline{\mathrm{N}_{0} \mathrm{P}_{0} \mathrm{~K}_{0}}$ & 2.75 & 0.40 & 2.69 & -8 & 10 & -2 & 54.2 \\
\hline $\mathrm{N}_{112} \mathrm{P}_{0} \mathrm{~K}_{0}$ & 3.45 & 0.37 & 1.95 & 6 & 9 & -14 & 62.8 \\
\hline $\mathrm{N}_{112} \mathrm{P}_{0} \mathrm{~K}_{168}$ & 3.29 & 0.34 & 4.92 & -10 & -5 & 15 & 70.8 \\
\hline $\mathrm{N}_{0} \mathrm{P}_{112} \mathrm{~K}_{0}$ & 2.81 & 0.60 & 2.79 & -18 & 26 & -8 & 48.4 \\
\hline $\mathrm{N}_{112} \mathrm{P}_{112} \mathrm{~K}_{0}$ & 3.42 & 0.53 & 1.78 & 1 & 25 & -26 & 63.9 \\
\hline $\mathrm{N}_{111} \mathrm{P}_{11} \mathrm{~K}_{16}$ & 3.33 & 0.55 & 4.98 & -18 & 9 & 9 & 72.2 \\
\hline $\mathrm{N}_{0} \mathrm{P}_{0} \mathrm{~K}_{168}$ & 2.79 & 0.45 & 4.44 & -19 & 8 & 12 & 53.3 \\
\hline $\mathrm{N}_{112} \mathrm{P}_{0} \mathrm{~K}_{168}$ & 3.29 & 0.34 & 4.92 & -10 & -5 & 15 & 70.8 \\
\hline $\mathbf{N}_{0} \mathbf{P}_{112} \mathbf{K}_{168}$ & 2.60 & 0.67 & 4.78 & -36 & 25 & 12 & 51.0 \\
\hline $\mathrm{N}_{112} \mathrm{P}_{112} \mathrm{~K}_{168}$ & 3.33 & 0.55 & 4.98 & -18 & 9 & 9 & 72.2 \\
\hline $\mathrm{LSD}_{0,05}$ & & & & & & & 7.8 \\
\hline
\end{tabular}

the norms provided in Table 2 and values from the first line of Table 3:

where

Negative indices indicate relative insufficiency; relative excess is indicated by positive values. A diagnosis of the most limiting nutrient was made for each treatment combination beginning with the control, or the lowest treat- ment level. The diagnoses were considered accurate if the next treatment containing the nutrient identified as limiting resulted in a yield increase. The inverse set of norms from the ones chosen for the program were used to calculate indices that were evaluated in the same manner.

\section{Results and Discussion}

The treatments in the field experiments were successful in inducing differences in yield and leaf tissue nutrient content. The highest yields exceeded $45 \mathrm{Mg} \cdot \mathrm{ha}^{-1}$, which is considered good by the industry. Leaf tissue nutrient content responded to fertilizer treatments, and the $\mathrm{N}$ and $\mathrm{P}$ applications resulted in significant yield responses. The split applications of $\mathrm{S}$ and $\mathrm{P}$ resulted in no significant differences. The total data set from which the norms were established contained 1038 observations, while the high-yielding subset contained 173. The norms and corresponding coefficients of variation are presented in Table 2 .

To test the diagnostic precision of these norms, several studies in which significant yield responses resulted from treatments were selected from the literature. Using the tissue data provided, indices were calculated. The results of this procedure are presented in Tables 3-5 for various sets of data. Beginning with Table 3, the DRIS $\mathrm{N}$ index for the control treatment is -8 , the most negative. Treatment $\mathrm{N}_{112} \mathrm{P}_{0} \mathrm{~K}_{0}$ resulted in a significant increase in yield, with $\mathrm{K}$ becoming the most limiting nutrient. When $\mathrm{K}$ was added, a further significant yield increase resulted. Nitrogen then becomes insufficient, but no higher $\mathrm{N}$ rate existed. With treatment $\mathrm{N}_{0} \mathrm{P}_{112} \mathrm{~K}_{0}$ taken as the starting point, a requirement for $\mathrm{N}$ was suggested. The application of $\mathrm{N}$ resulted in a significant yield response and a $\mathrm{K}$ insufficiency. The addition of $\mathrm{K}$ produced another significant yield increase.

In a fertilizer test that included two singlefactor experiments, the proposed diagnostic norms were also successful in predicting yield responses to applied $\mathrm{P}$ and $\mathrm{Mg}$. The data presented in Table 4 are from a greenhouse study conducted in the former USSR (Pankov, 1984). In the study in which $P$ was varied, yields increased up to treatment $P_{31}$, at which point $\mathrm{P}$ was no longer indicated as limiting. The next level of $P$ resulted in no significant change in yield. In the same way, the $\mathrm{Mg}$ norm was successful in predicting yield responses to Mg applications.

By using the sufficiency ranges $3.0 \%$ to $3.8 \% \mathrm{~N}, 0.27 \%$ to $0.40 \% \mathrm{P}, 2.0 \%$ to $3.4 \% \mathrm{~K}$, $0.9 \%$ to $1.7 \% \mathrm{Ca}$, and $0.18 \%$ to $0.38 \% \mathrm{Mg}$ developed by Pankov (1984) from single-factor greenhouse and field fertilizer trials, diagnoses identical to those using the DRIS norms were made for all the above studies. This success is not unusual in that nutrient intensity as well as balance can govern yield. So long as good values are used, sufficiency ranges can adequately detect nutrient limitations in the cases where nutrient intensity is more important than nutrient balance in governing yield. The DRIS indices calculated (Table 5) from the means of Pankov's sufficiency ranges show that, even though the means are below the DRIS concentration norms, they are in close balance. It is when the lower and upper extremes of these ranges are considered that inherent weaknesses in the sufficiency range approach become evident. When DRIS indices are calculated using a random combination of both lower and upper limits of these ranges, the possibility is demonstrated that a yield-limiting imbalance could exist within the confines of good sufficiency ranges. In this particular combination, the $\mathrm{Mg}$ index is -9 , indicating that a $\mathrm{Mg}$ insufficiency could go undiagnosed, although the $\mathrm{Mg}$ concentration is within the sufficiency range when the mean of the range was used (Table 5).

The DRIS indices calculated from experimental field data (Table 6), in which four levels of $\mathrm{Cu}$ were applied, point to $\mathrm{Cu}$ as the most limiting factor in the control. The next

Table 4. Effects of $\mathrm{P}$ or Mg fertilization on onion tissue nutrient content, yield, and DRIS indices from greenhouse studies by Pankov (1984).

\begin{tabular}{|c|c|c|c|c|c|c|c|c|c|c|c|}
\hline \multirow[b]{2}{*}{ Treatment ${ }^{2}$} & \multicolumn{5}{|c|}{ Leaf composition (\% dry wt) } & \multicolumn{5}{|c|}{ DRIS indices } & \multirow{2}{*}{$\begin{array}{c}\text { Yield } \\
\text { (g/pot) }\end{array}$} \\
\hline & $\mathrm{N}$ & $\mathrm{P}$ & $\mathrm{K}$ & $\mathrm{Ca}$ & $\mathrm{Mg}$ & $\mathrm{N}$ & $\mathrm{P}$ & $\mathrm{K}$ & $\mathrm{Ca}$ & $\mathrm{Mg}$ & \\
\hline$\overline{\mathrm{P}_{3.9}}$ & 2.87 & 0.14 & 2.94 & 1.04 & 0.20 & 6 & -25 & 10 & 1 & 8 & 180 \\
\hline $\mathrm{P}_{7.5}$ & 2.80 & 0.18 & 2.67 & 1.09 & 0.20 & 3 & -12 & 5 & 1 & 4 & 264 \\
\hline $\mathrm{P}_{15}$ & 2.77 & 0.24 & 2.62 & 1.20 & 0.21 & -1 & -4 & 3 & 2 & 1 & 310 \\
\hline $\mathrm{P}_{31}$ & 2.83 & 0.34 & 2.60 & 1.37 & 0.22 & -4 & 3 & 0 & 2 & -1 & 343 \\
\hline $\mathrm{P}_{93}$ & 2.80 & 0.53 & 2.59 & 1.38 & 0.22 & -9 & 18 & -4 & 0 & -5 & 349 \\
\hline $\mathrm{LSD}_{0.05}$ & & & & & & & & & & & 37 \\
\hline $\mathrm{Mg}_{0}$ & 3.06 & 0.41 & 2.52 & 0.95 & 0.10 & 6 & 20 & 4 & -2 & -28 & 261 \\
\hline $\mathrm{Mg}_{4}$ & 2.99 & 0.40 & 2.48 & 0.92 & 0.15 & 2 & 14 & 1 & -6 & -11 & 320 \\
\hline $\mathrm{Mg}_{12}$ & 2.94 & 0.34 & 2.53 & 0.88 & 0.20 & 1 & 7 & 1 & -8 & -1 & 410 \\
\hline $\mathrm{Mg}_{36}$ & 2.90 & 0.34 & 2.59 & 0.88 & 0.28 & -2 & 4 & 0 & -11 & 8 & 421 \\
\hline $\mathrm{Mg}_{108}$ & 2.83 & 0.31 & 2.50 & 0.76 & 0.42 & -5 & -1 & -1 & -20 & 27 & 415 \\
\hline $\mathrm{LSD}_{0.05}$ & & & & & & & & & & & 42 \\
\hline
\end{tabular}

${ }^{2}$ Treatments in $\mathrm{mg} \cdot \mathrm{liter}^{-1}$ substrate. 
Table 5. DRIS indices calculated from the means and a combination of the lower and upper limits of the sufficiency ranges in percent dry weight for onions, as proposed by Pankov (1984). (Example demonstrates the possibility of nutritional imbalance within sufficiency ranges.)

\begin{tabular}{llllll}
\hline \hline Criterion & $\mathrm{N}$ & $\mathrm{P}$ & $\mathrm{K}$ & $\mathrm{Ca}$ & $\mathrm{Mg}$ \\
\hline Mean of range & 3.4 & 0.33 & 2.5 & 1.2 & 0.25 \\
DRIS indices & 1 & 1 & -2 & -2 & 2 \\
Range extremes & 3.0 & 0.40 & 2.0 & 1.7 & 0.18 \\
DRIS indices & -3 & 10 & -8 & 10 & -9 \\
\hline
\end{tabular}

level of $\mathrm{Cu}$ produced no change in yield while lowering the magnitude of the $\mathrm{Cu}$ index. With treatment $\mathrm{Cu}_{2}$, a significant yield increase occurred and $\mathrm{N}$ became slightly more insufficient than $\mathrm{Cu}$. The highest level of $\mathrm{Cu}$ resulted in no further significant yield response.

When we calculated indices for the same data with the alternate set of norms, similar results were obtained (results not shown). When significant yield increases were found, these norms predicted the same insufficiency. The DRIS onion foliar norms for N, P, K, Mg, and $\mathrm{Cu}$ have been shown through testing to have diagnostic precision and are suitable for use. It is probable that the $\mathrm{S}$ norms are also valid since the norms were calculated from results in which $S$ was a treatment, but these could not be validated due to a lack of independent data. The norms for the remaining nutrients should be used with caution since they have not been verified nor were they derived from data in which these nutrients were controlled.

\section{Literature Cited}

Angeles, D.E., M.E. Sumner, and N.W. Barbour. 1990. Preliminary nitrogen, phosphorus, and potassium DRIS norms for pineapple. HortScience 25:652-655.

Beaufils, E.R. 1957. Research for rational exploitation of Hevea using a physiological diagnosis based on the mineral analysis of various parts of the plants. Fertilite 3:27-38.

Beaufils, E.R. 1973. The Diagnosis and Recommendation Integrated System (DRIS). Soil Sci. Bul. 1, Univ. of Natal, South Africa.

Bishop, R.F., E.W.Chipman, and C.R. MacEachern. 1972. Effect of nitrogen, phosphorus and potassium on yields and nutrient levels in onions grown on a sphagnum peat soil. Commun. Soil Sci. Plant Anal. 3:97-111.

Davee, D.E., T.L. Righetti,E. Fallahi, and S. Robbins. 1986. An evaluation of the DRIS approach for identifying mineral limitations on yield in 'Napoleon' sweet cherry. J. Amer. Soc. Hort. Sci. 111:988-993.

Ewali, A.M.O. and G.J. Gascho. 1984. Soil testing, foliar analysis, and DRIS as guides for sugar cane fertilization. Agron. J. 76:466-470.

Grove, J.H. and M.E. Sumner. 1982. Yield and leaf composition of sunflower in relation to $\mathrm{N}, \mathrm{P}, \mathrm{K}$, and lime treatments. Fert. Res. 33:367-378.

Isaac, R. and W.C. Johnson. 1984. Methods of soil and plant analysis. Univ. of Georgia, Athens.

Lagatu, H. and L. Maume. 1924. Évolution remarquablement régulière de certain rapports physiologiques (chaux, magnésie, potasse) dans les feuilles de la vigne bien alimentée. Comptes Rendus Acad. Sci. 179:782-785.

Letzsch, W.S. and M.E. Sumner. 1983. Computer program for calculating DRIS indices. Commun. Soil Sci. Plant Anal. 14:811-815.

Mathur, S.P., A. Belanger, M. Valk, C.M. Preston, E. Knibbe, and R.B. Sanderson. 1983. A study of onions grown in microplots on three organic soils each containing four levels of copper. Can. J. Soil Sci. 63:221-228.

Minotti, P.L. and K.W. Stone. 1988. Consequences of not fertilizing onions on organic soils with high soil test values. Commun. Soil Sci. Plant Anal. 19:1887-1906.

Painter, C.G. 1977. The effect of nitrogen, phosphorus, potassium and micronutrients on yield, grade and storage of onion bulbs in southwestern Idaho. Idaho Agr. Expt. Sta. Bul. 574, Idaho Univ. Res. \& Ext. Ctr., Twin Falls.

Pankov, V.V. 1984. Leaf analysis in relation to onion nutrition, p. 449-456. In: P. Martin Prével (publisher).Vlth Proceedings International Colloquium for the Optimization of Plant $\mathrm{Nu}$ trition, Montpellier, France.

Piggott, T.J. 1986. Vegetable crops, p. 148-187. In: D.J.Reuter and J.B. Robinson (eds.). Plant analysis: An interpretation manual. Inkata Press, Sydney, Australia.

Rathfon, R.A. and J.A. Burger. Diagnosis and Recommendation Integrated System modifications for Fraser fir Christmas trees. Soil Sci. Soc. Amer. J. 555:1026-1031.

SAS Institute. 1983. SAS user's guide: Statistics. 1983 ed. SAS Inst., Cary, N.C.

Shear, C.B., H.L. Crane, and A.T. Myers. 1946. Nutrient-element balance: A fundamental concept in plant analysis. Proc. Amer. Soc. Hort. Sci. 47:239-248.

Sumner, M.E. 1977. Preliminary N P K foliar diagnostic norms for wheat. Commun. Soil Sci. Plant Anal. 8:149-167.

Sumner, M.E. 1990. Advances in the use and application of plant analysis. Commun. Soil Sci. Plant Anal. 21:1409-1430.

van Lierop, W., Y.A. Martel, and M.P. Cesas. 1980. Optimal soil $\mathrm{pH}$ and sufficiency concentrations of $\mathrm{N}, \mathrm{P}$, and $\mathrm{K}$ for maximum alfalfa and onion yields on acid organic soils. Can. J. Soil Sci. 60:107-117.

Walworth, J.L. and M.E. Sumner. 1987. The Diagnosis and Recommendation Integrated System. Adv. Soil Sci. 6:149-188.

Walworth, J.L. and M.E. Sumner. 1988. Foliar diagnosis: A review. Adv. Plant Nutr. 3:193-241.

Table 6. Effects of $\mathrm{Cu}$ application in the field on leaf composition, yield, and DRIS indices of onions calculated from the data of Mathur et al. (1983).

\begin{tabular}{|c|c|c|c|c|c|c|c|c|c|c|c|c|c|c|c|c|c|}
\hline \multirow[b]{2}{*}{ Treatment $^{\mathrm{y}}$} & \multicolumn{8}{|c|}{ Leaf composition $^{2}$} & \multicolumn{8}{|c|}{ DRIS indices } & \multirow{2}{*}{$\begin{array}{c}\text { Yield } \\
\text { (kg/plot) }\end{array}$} \\
\hline & $\mathrm{N}$ & $\mathrm{P}$ & $\mathrm{K}$ & $\mathrm{Ca}$ & $\mathrm{Mg}$ & $\mathrm{Mn}$ & $\mathrm{Zn}$ & $\mathrm{Cu}$ & $\mathrm{N}$ & $\mathrm{P}$ & $\mathrm{K}$ & $\mathrm{Ca}$ & $\mathrm{Mg}$ & $\mathrm{Mn}$ & $\mathrm{Zn}$ & $\mathrm{Cu}$ & \\
\hline$\overline{\mathrm{Cu}_{0}}$ & 2.80 & 0.45 & 2.84 & 1.72 & 0.33 & 88.2 & 43.1 & 4.09 & -7 & 12 & 2 & 13 & 16 & 1 & 16 & -53 & $5.72 \mathrm{a}^{\mathrm{x}}$ \\
\hline $\mathrm{Cu}_{1}$ & 2.50 & 0.51 & 2.55 & 1.62 & 0.31 & 84.5 & 37.1 & 7.47 & -12 & 14 & -2 & 7 & 9 & -3 & 7 & -21 & $5.73 \mathrm{a}$ \\
\hline $\mathrm{Cu}_{2}$ & 2.15 & 0.40 & 2.63 & 1.40 & 0.30 & 76.9 & 51.0 & 8.75 & -17 & 7 & -1 & 4 & 9 & -5 & 19 & -16 & $8.18 \mathrm{~b}$ \\
\hline $\mathrm{Cu}_{3}$ & 3.07 & 0.40 & 2.71 & 1.39 & 0.30 & 84.4 & 53.8 & 14.65 & -7 & 3 & -3 & 0 & 5 & -6 & 14 & -5 & $7.21 \mathrm{~b}$ \\
\hline
\end{tabular}

${ }^{2} \mathrm{~N}, \mathrm{P}, \mathrm{K}, \mathrm{Ca}$, and $\mathrm{Mg}$ concentration are in percent dry weight, and $\mathrm{Mn}, \mathrm{Zn}$, and $\mathrm{Cu}$ are in $\mathrm{mg} \cdot \mathrm{kg}^{-1}$.

yTreatment subscripts indicate increasing levels of soil $\mathrm{Cu}$.

${ }^{x}$ Mean separation for yield by Duncan's multiple range test at $P \leq 0.05$. 